https://dx.doi.org/10.4314/ijs.v23i2.6

Ife Journal of Science vol. 23, no. 2 (2021)

\title{
SOIL QUALITY AND METAL DISTRIBUTION AROUND STONE QUARRIES WITHIN ABEOKUTA, SOUTHWEST, NIGERIA
}

\author{
*Olatunde, K.A., Towolawi, T., Kolawole, I., Aiyelabola, N., Michael, O., Warrie, E., \\ Oludiran, O. and Awomade, I. \\ Department of Environmental Management and Toxicology, Federal University of Agriculture, Abeokuta, PMB 2240, \\ Ogun State, Nigeria \\ *Corresponding author's email: olatundeka@funaab.edu.ng \\ (Received: $15^{\text {th }}$ March, 2021; Accepted: $7^{\text {th }}$ June, 2021)
}

\section{ABSTRACT}

\begin{abstract}
Quarrying activities are explored to extract a variety of materials deposited underneath the earth surface. These activities however can potentially impact negatively on soil quality and cause elemental pollution. This study assessed soil quality and distribution of metals in soils around four quarrying sites (PAPA, S\&D, TCity and Mile 8) within Abeokuta, Ogun State, Nigeria. Thirty six topsoil samples were collected at distances from quarry gates in September 2019 and analyzed using standard methods. Soil quality and metal concentrations were compared with reference and standards and the degrees of soil contamination assessed using relevant indices. Soil quality reduced with distance from the quarry gates. Similarly, metal concentrations had strong and significant $(\mathrm{P}=0.05)$ negative relationships with distance and were higher in soil samples compared to the reference. Moderate contaminations for all metals were observed in soils collected close to the quarry gates soils from the results of the contamination factor index $\left(C_{f}\right)$. However, the results of ecological risk index $(E)$ showed that the metal loads in soils currently do not pose any ecological risk.
\end{abstract}

Keywords: Quarry, Soil quality, Metal distribution, Soil contamination, Potential ecological risk

\section{INTRODUCTION}

Quarrying is an immemorial activity explored for different deposited minerals such as limestone and granite for construction and related purposes. Despite its importance in development, quarrying could potentially be a destructive developmental activity as its socio-economic benefits hardly compensates for the overall detrimental effects on natural ecological systems (Melodi, 2017).

The potential effects of reduced soil quality and elemental pollution from quarrying activities can be diverse. Metal pollutants in dust released from the quarries can cause significant health problems for residents. Metals in air which settle on soil and plants may also affect agriculture causing poor vegetation growth and lowering plant resistance against pests and diseases (Olatunde et al., 2020; Adeyanju and Okeke, 2019; Morkunas et al., 2018), ultimately lowering food availability and financial strength of local residents who are primarily agrarian. More importantly is the potential of these metals to bioaccumulate through the grown crops and bioconcentrate through the food chain (Bilen, 2010).

Soil pollution from human activities such as quarrying with its dry process can drastically reduce soil moisture and soil organic contents (Zwolak et al., 2019). It can also alter soil pH causing retention of undesirable metals thereby affecting soil quality (Julie et al., 2018). The best measure to know the extent of and abate pollution of the environment is quantification of pollutants and comparing their determined levels with the background values or stipulated standards, thus, this study.

Few studies have investigated the effect quarrying has on environmental quality within Abeokuta, Nigeria. Most of the studies have focused on air quality (Melodi, 2017) and human health (Oguntoke el al., 2009) and there is less emphasis on soil quality. Assessing soil quality and elemental content of soils around quarry sites within Abeokuta is extremely important due to current expansion in quarrying activities and the need to ensure maintenance of soil quality for agriculture. This should also form part of an environmental monitoring process due to the indestructible nature and the toxic effects of metals on living organisms. Hence, this study investigated soil quality, metal distribution and potential ecological risk posed by possible contamination in soils 
around four major quarry sites within Abeokuta, southwest Nigeria.

\section{METHODS}

\section{Study Area}

Four quarries within Abeokuta, an ancient town in Ogun State, southwest Nigeria were investigated in this study. The town is located in a hummocky terrain with distinct undulating topography and prominent hills characterized by steep slope varying in altitude between $30 \mathrm{~m}$ and $180 \mathrm{~m}$ above sea level (Akinse and Gbadebo, 2016). It is also a border state to Lagos (an economic nerve centre in Nigeria) and has a geology consisting of Coastal
Plain Sand. The study sites from which soil samples were collected for this study include PAPA, S\&D, TCity and MLL8 quarries and are described in Figure I. The four quarries are located in rural communities and are surrounded by villages whose inhabitants are mainly farmers with their farms only a few kilometres from the quarry sites. Over the past years, the number of quarry companies within Abeokuta has increased greatly due to the abundance of granite deposits within the area. These deposits mostly exist as an outcrop and do not usually require stripping the overburden (Melodi, 2017).

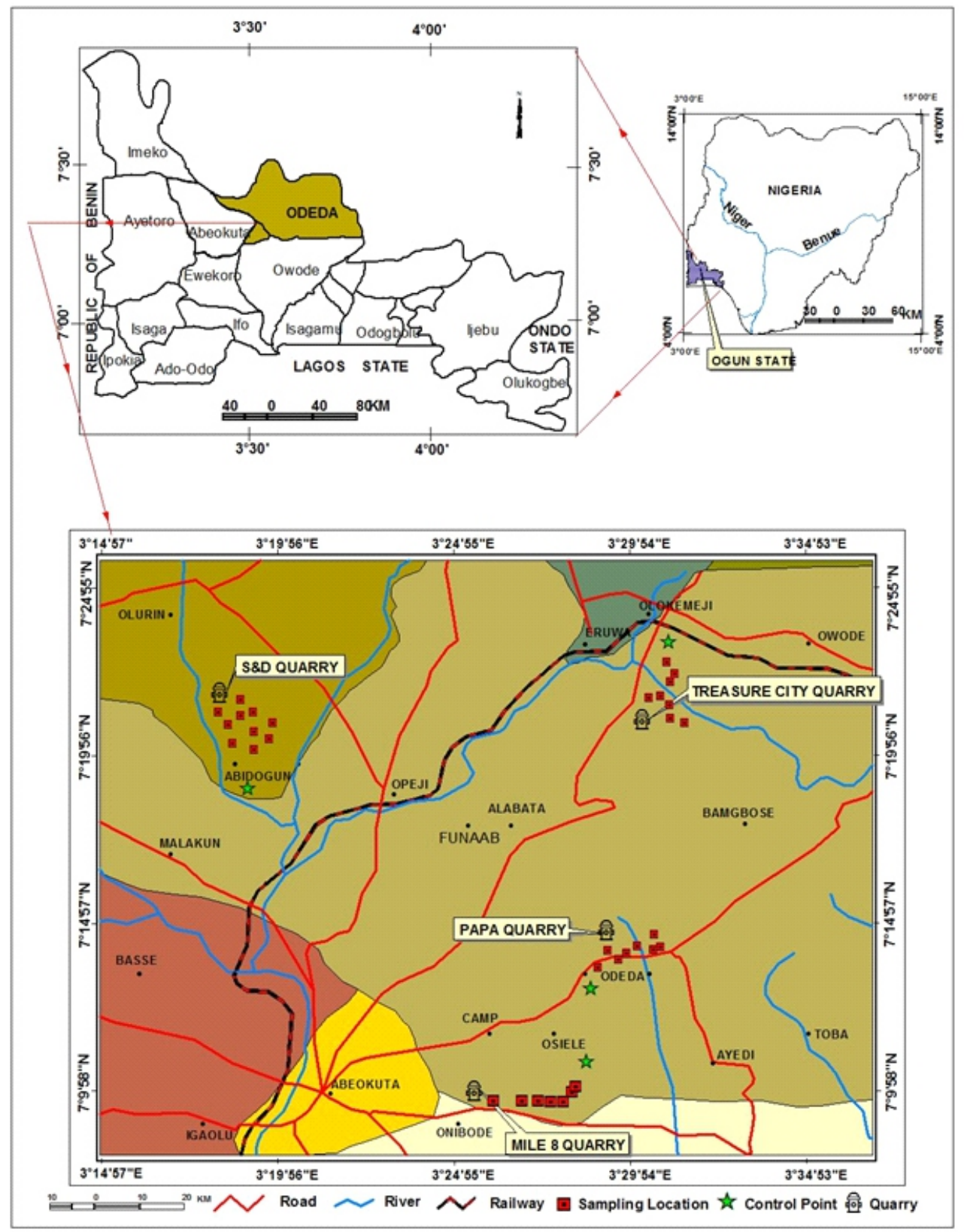

Figure I. Map of the study area 
Samples Collection and Analysis

Topsoil $(0-15 \mathrm{~cm})$ samples were collected from eight sampling locations at increasing distances (approximately $100 \mathrm{~m}$ apart) from each quarry gate. Samples from each location consisted of four subsamples randomly collected and bulked. To reduce unaccounted interferences in heavy metal soil content, soil samples were collected away from farms, waste disposal sites and other human activities that can potentially impact on heavy metal content of soils. In addition, a reference site, relatively undisturbed $\sim 2 \mathrm{~km}$ away from each quarry gate was identified and 5 samples collected and pooled in the field to represent the REF soil, making a subtotal of 9 samples for each quarry site and a final total of 36 samples for this study. Soil samples were air dried, homogenized, sieved with $2 \mathrm{~mm}$ mesh sized sieves and stored in labelled polythene bags prior to analysis.

Soil $\mathrm{pH}$ and electrical conductivity were determined in soil-water extract using a D-6 Dialysate meter. $20 \mathrm{~g}$ of processed soil was thoroughly mixed with $20 \mathrm{~mL}$ of distilled deionised water for 30 minutes. The mixture was left to stand for one hour and the readings were taken from the soil-water mixture using the $\mathrm{pH}$ electrode. Total organic carbon (TOC) was determined by oxidation with potassium dichromate and titration with ferrous sulphate reagent (FAO, 2019). The soil organic matter (SOM) content was determined by multiplying the total organic carbon content by 1.724 (Okebalama, 2017). Total nitrogen was determined by Kjeldahl's digestion ( $\mathrm{He}$ et al., 1990). Available phosphorus (P) and soil boron (B) were determined in the soil extracts by Hach DR/2000 spectrophotometer while Potassium (K) was determined using the PerkinElmer PinAAcle 500 FAA spectrometer.

Approximately $0.25 \mathrm{~g}$ of each soil sample was weighed and $6 \mathrm{~mL}$ of freshly prepared aqua-regia $\left(\mathrm{HNO}_{3} / \mathrm{HCl}\right.$ mixture, 1:3) was added and heated in a water bath at $60^{\circ} \mathrm{C}$ for 1 hour. An additional 6 $\mathrm{mL}$ of digestion mixture was added and the slurry heated for an additional hour. The solution was allowed to cool. The digested samples were centrifuged at 15,000 rpm for $10 \mathrm{~min}$ and filtered (Whatman $0.45 \mu \mathrm{m}$ ) into a $100 \mathrm{ml}$ volumetric flask, and made up to mark with distilled deionised water (Das and Ting, 2017). The concentrations of heavy metals (Fe, Mn, $\mathrm{Cu}$ and $\mathrm{Zn}$ ) in extract were determined by Microwave Plasma Atomic Emission Spectroscopy (MP-AES 4200).

Blanks and standard reference materials (BCR 141R, Calcareous Loam Soil) contaminated with known quantities of metal salts were included in the extraction procedures to verify the efficiency of the extraction. The detection limits for all heavy metals studied were below $0.07,0.41,0.15$, 0.05 and $0.12 \mathrm{mg} \mathrm{kg}^{-1}$ for $\mathrm{Fe}, \mathrm{Mn}, \mathrm{Cu}$ and $\mathrm{Zn}$ respectively) and an average recovery of $74.1 \%$ for metals in the reference material.

\section{Assessment of Soil Contamination}

The extent of metal contamination at each of the sampling points were determined by comparing metal concentrations in soils with the REF (geochemical background) obtained from an undisturbed location $\sim 2 \mathrm{~km}$ away from the quarry gate. The degree of contamination was assessed using the contamination factor and the potential ecological risk index.

\section{Contaminantfactor}

Contaminant factor $(C f)$ is an index obtained by dividing concentration of each metal in the soil sample by the metal concentration in the REF (Maanan et al., 2014). A $C_{f} \leq 1$ designates low pollution; $1<C_{f} \leqslant 3$ is moderate pollution; $3<C_{f}$ $\leq 6$ is considerable pollution; and $C_{f}>6$ is very high pollution.

$C_{f}=\frac{C_{i}}{B}$

Where $C_{i}$ is the concentration of the metal in the soil sample and $B$ concentration of the metalis the REF (i.e. the concentration of the metal in the perceived unpolluted sample).

\section{Assessment of PotentialEcological Risk}

This index evaluates the potential ecological risk posed by heavy metal pollution in accordance with the toxicity of individual heavy metals:

$E^{i}=T_{r}^{i} * C_{f}$

Where $E^{i}$ is the individual potential ecological risk factor and $C_{f}$ is the contamination factor. $\mathrm{T}_{\mathrm{r}}^{\mathrm{i}}$ is the toxic response factor, characterizing the potential 
of metal pollution by representing the toxicity of metals. The normalized toxic response factor suggested for $\mathrm{Cu}, \mathrm{Mn}, \mathrm{Zn}$, and $\mathrm{Fe}$ are 5, 1, 1, and 5 respectively (Nouri and Haddioui, 2016)

\section{Statistical analysis}

The results obtained from laboratory analysis were analyzed using SPSS 23.0 (SPSS Inc., USA) software. Data were subjected to descriptive statistics and a correlation analysis was used to evaluate the relationship between soil quality parameters and distance from the quarry gate. A Pearson correlation analysis (PCR) was conducted to evaluate the relationships between the different parameters while an analysis of variance (ANOVA) was also conducted to compare soil quality parameters across the four quarries.

\section{RESULTS AND DISCUSSION}

Results of soil analysis from each quarry site are presented in Table I, while the average results of soil $\mathrm{pH}, \mathrm{EC}, \mathrm{TOC}$, nutrients (B,N,P and $\mathrm{K}$ ) and metals $(\mathrm{Cu}, \mathrm{MN}, \mathrm{Fe}, \mathrm{Zn})$ in soils around quarries within the study area is presented in Table II.

$\mathrm{pH}$ reflects the health status of soil and can be a good indicator for nutrient problems. While the desirable soil $p H$ range for optimum plant growth for each crops varies, a soil pH between $6.0-7.5$ is generally acceptable for most plants as most nutrients become less available to plants beyond this boundaries (Neina, 2019). The $\mathrm{pH}$ values of topsoil samples from all quarries are acidic to slightly alkaline ranging from 5.63 to 7.92. Majority of topsoil samples fell within acceptable $\mathrm{pH}$ range, with the exception of three samples around TCity and MIL8 quarries all within $100 \mathrm{~m}$ of the quarry gate. Average $\mathrm{pH}$ of all topsoil samples within this study was found to be 6.85 . Repeated deposition of quarry dusts containing chemicals to the soil can result in severe acidity build up in the soil system.

The EC values in samples within the study area ranged between $34-267 \mu \mathrm{S} / \mathrm{cm}$ with an average of $108.4 \mu \mathrm{S} / \mathrm{cm}$ for the study area. Levels of EC in samples collected close to the quarry gates were found to be lower compared to REF soils (Table I). The TOC levels in the investigated soil samples were also found to be lower than in the reference soil ranging between $0.3 \%$ and $3.82 \%$ (Table II). The lowest TOC content was found around the PAPA quarry, approximately $100 \mathrm{~m}$ from the quarry gate. Contaminated soils are usually described by the presence of minimal nutrient content (Freitas et al., 2004). 
Olatunde $\boldsymbol{e t}$ al.: Soil Quality and Metal Distribution around Stone Quarries

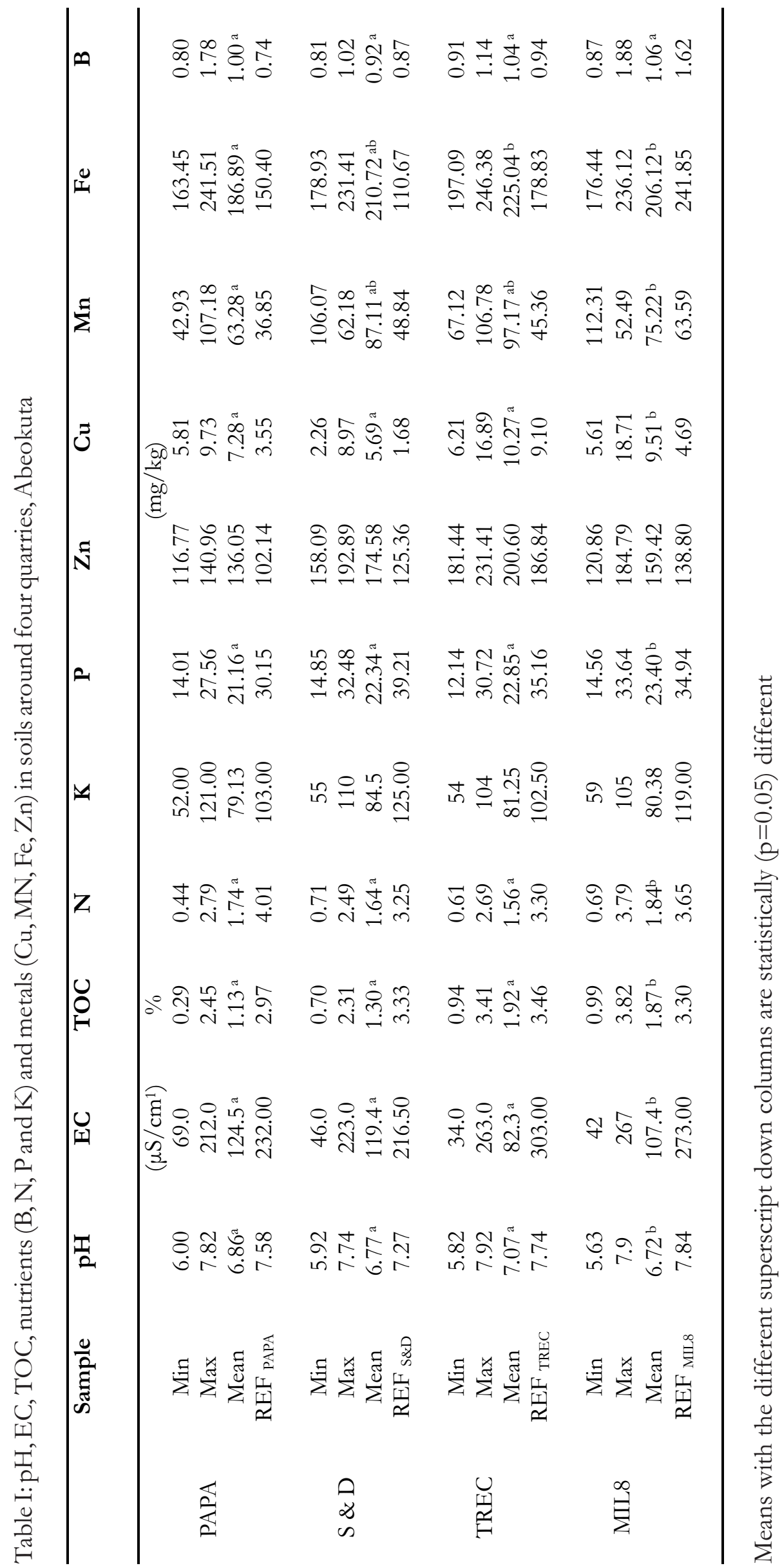




\section{Plant Nutrients}

Macronutrients such as nitrogen, potassium, phosphorous and micronutrient (boron) are essential elements required by plants in specific quantities because of their contribution to plant growth. The highest available nitrogen (3.79 $\mathrm{mg} / \mathrm{kg}$ ) in topsoil samples was recorded at MIL8 at a distance $\sim 700 \mathrm{~m}$ away from the quarry gate. Lowest available nitrogen value $(0.4 \mathrm{mg} / \mathrm{kg})$ was found in topsoil collected at the PAPA quarry gate. Nitrogen and ammonia in soils are produced by the action of microorganisms on the soil organic matter. Soils close to quarrying activities may contain significant amount of contaminant containing dusts and depositions which inhibit microbial activities thereby reducing the available nitrogen content of soils. Similarly, the least concentrations of phosphorus and potassium around all four quarries studied were found in topsoil samples closest to the quarry gates. Phosphorus has an average of $22.4 \mathrm{mg} / \mathrm{kg}$ and ranges from $12.1 \mathrm{mg} / \mathrm{kg}$ to $33.6 \mathrm{mg} / \mathrm{kg}$ (Table II). Potassium has an average of $81.4 \mathrm{mg} / \mathrm{kg}$ and ranges from $50 \mathrm{mg} / \mathrm{kg}$ to $121 \mathrm{mg} / \mathrm{kg}$. The highest concentration of potassium was found at MIL8, $\sim 500 \mathrm{~m}$ from the quarry gate while the highest concentration of phosphorus was found at $\sim 600 \mathrm{~m}$ to the PAPA quarry gate. Boron is a micronutrient occurring as borates or borosilicates in the soil. It plays an integral part in a plant's reproductive cycle, controlling processes such as flowering and pollen production. The optimum boron range for most crops is $0.5-2$ $\mathrm{mg}$, and lower and higher values indicate deficiency and toxicity (Koshiba, 2009). Boron in topsoil within the study area ranged between 0.80 $\mathrm{mg} / \mathrm{kg}$ to $1.87 \mathrm{mg} / \mathrm{kg}$ with an average of 1 $\mathrm{mg} / \mathrm{kg}$. Boron is usually associated with leaching from acidic sandy soils.

\section{Metals Content of Soils}

Zinc and iron are the dominant metals in soil within the study area. Generally, the order of metal contents in topsoil samples was $\mathrm{Fe}>\mathrm{Zn}>$ $\mathrm{Mn}>\mathrm{Cu}$ (Table I). Iron ranged between 163.5 $\mathrm{mg} / \mathrm{kg}$ to $246.4 \mathrm{mg} / \mathrm{kg}$ with an average of 207.2 $\mathrm{mg} / \mathrm{kg}$ for the study area. The zinc content of soil samples ranged between $188.91 \mathrm{mg} / \mathrm{kg}$ and $231.41 \mathrm{mg} / \mathrm{kg}$ with an average of $167.7 \mathrm{mg} / \mathrm{kg}$ for the study area (Table II). Manganese ranged between $42.9 \mathrm{mg} / \mathrm{kg}$ and $207.1 \mathrm{mg} / \mathrm{kg}$ with an average of $80.71 \mathrm{mg} / \mathrm{kg}$. Copper had the least concentration in topsoil and ranged between 2.6 $\mathrm{mg} / \mathrm{kg}$ to $18.7 \mathrm{mg} / \mathrm{kg}$ with an average of 8.2 $\mathrm{mg} / \mathrm{kg}$ for the study area. The metal concentrations in soil were compared with regulatory standards grouped under threshold and permissible limits (Table II). The threshold limit is used to checkmate the minimum toxicity in all soil environments while the permissible limit is applicable to agricultural soils. Soils whose metal contents exceeds the permissible limit are termed contaminated for agricultural activities and are associated with ecological or human health risks (Toth et al., 2016). Zinc contents of soils at Tcity and MIL8 quarry gates were above $200 \mathrm{mg} / \mathrm{kg}$ limit for agricultural soil and can present both ecological and health risks. Soil samples from around MIL8 quarry were significantly $(p=0.05)$ different from soils around the three other quarries with respect to most of the parameters. 
Table II: Comparison of present study results (mean) with guideline values for heavy metals in soils.

\begin{tabular}{ccccc}
\hline & \multicolumn{2}{c}{ Present study } & Maximum allowable limit(Toth et al., \\
& & & 2016) \\
& Mean & Range & & Permissible limits \\
& 8.19 & $2.58-18.71$ & 100 & \\
$\mathrm{Cu}(\mathrm{mg} / \mathrm{kg})$ & 80.71 & $42.93-207.11$ & 2000 & \\
$\mathrm{Mn}(\mathrm{mg} / \mathrm{kg})$ & 207.19 & $163.45-246.38$ & 50000 & \\
$\mathrm{Fe}(\mathrm{mg} / \mathrm{kg})$ & 167.66 & $188.91-231.41$ & 200 & \\
$\mathrm{Zn}(\mathrm{mg} / \mathrm{kg})$ & 1.00 & $0.80-1.88$ & & \\
$\mathrm{~B}(\mathrm{mg} / \mathrm{kg})$ & 1.69 & $0.40-3.79$ & & \\
$\mathrm{~N}(\mathrm{mg} / \mathrm{kg})$ & 22.40 & $12.10-33.60$ & & \\
$\mathrm{P}(\mathrm{mg} / \mathrm{kg})$ & 81.40 & $50.00-121.00$ & & \\
$\mathrm{~K}(\mathrm{mg} / \mathrm{kg})$ & 1.00 & $0.80-1.87$ & & \\
$\mathrm{~B}(\mathrm{mg} / \mathrm{kg})$ & 6.85 & $5.63-7.92$ & & \\
$\mathrm{pH}$ & 1.56 & $0.3-3.82$ & & \\
$\%$ Organic carbon & 108.38 & $34-267$ & & \\
$\mathrm{EC}(\mu \mathrm{s} / \mathrm{cm})$ & & & & \\
\hline
\end{tabular}

On comparison of soil samples with the reference soil (REF) in all four quarries locations studied, results show increasing concentrations of EC and TOC in soils with distance from the quarry gate. $\mathrm{pH}$ of soils closer to quarrying activities were slightly more acidic and higher concentrations of all metals were found in topsoil samples than in the REF soils obtained approximately $2 \mathrm{~km}$ from the quarry gates, indicating that rock quarrying and transport could be influencing soil quality and contribute to soil metal content in the study area. A pearson correlation analysis of soil metal concentrations with distance from quarry gates show strong negative relationships for $\mathrm{Cu}(\mathrm{r}=-$ 0.77 to -0.91$) ; \mathrm{Mn}(\mathrm{r}=-0.69$ to -0.73$) ; \mathrm{Zn}(-0.53$ to -0.87$)$ and Fe: (- 0.58 to -0.69$)$. Metal contaminants from quarries can be released as constituents of dusts from crushed rocks and spent explosives used in blasting activities. These become deposited and retained in the soil at distances from the source depending on wind velocity, direction and particle size distribution of soil particles (Olatunde et al., 2020). Similarly, major nutrients (N, P and $\mathrm{K}$ ) show increasing concentrations with increasing quarrying activities.

\section{Indices of Soil Contamination}

Contamination indices for each sampling point are presented in Table III. In general, a $C_{f}$ greater than 1 indicates a degree of contamination likely to be of anthropogenic origin (Zhang and Liu 2000). Results indicate low to moderate contamination across locations for all metals. Of all four metals studied, Fe and Mn are the most contaminating. The levels of metal contamination in soils were observed to decrease with increasing distance from the quarry gates. All samples collected from the quarry gates had moderate levels of contamination for all four metals.

Out of the four quarries studied, activities at Tcity and $S \& D$ were the most contaminating. There was moderate contamination with respect to $\mathrm{Zn}, \mathrm{Mn}$ and $\mathrm{Fe}$ in almost all soils collected around Tcity quarry and in most soils around S\&D quarry

The ecological risk posed by metal contamination levels in soil samples as estimated based on individual toxicities of each metal revealed that the metals poses none to low potential ecological risk. All values for $E^{i}$ were less than 40 . It should however be noted that this estimation has a weakness of being subjective and ignoring united antagonism of numerous metals (Nouri and Haddioui, 2016). 
Table III: Contamination factor $\left(C_{f}\right)$ of metals in soils around quarry sites, Abeokuta.

\begin{tabular}{|c|c|c|c|c|c|c|c|c|c|}
\hline & \multicolumn{9}{|c|}{ Approximate distance from quarry gate (m) } \\
\hline & Quarry & 0 & 100 & 200 & 300 & 400 & 500 & 600 & 700 \\
\hline \multirow{4}{*}{$\mathrm{Cu}$} & PAPA & 1.14 & 0.92 & 0.80 & 0.81 & 0.80 & 0.92 & 0.74 & 0.68 \\
\hline & $\mathrm{S} \& \mathrm{D}$ & 1.20 & 0.44 & 1.07 & 1.17 & 0.67 & 0.38 & 1.61 & 1.66 \\
\hline & Tcity & 1.33 & 0.76 & 0.67 & 0.95 & 1.36 & 0.52 & 1.55 & 1.78 \\
\hline & MIL8 & 1.27 & 1.24 & 0.48 & 0.47 & 0.47 & 0.88 & 0.38 & 0.54 \\
\hline \multirow[t]{4}{*}{$\mathrm{Mn}$} & PAPA & 1.41 & 0.82 & 0.77 & 0.91 & 0.67 & 0.76 & 0.77 & 0.57 \\
\hline & S\&D & 1.33 & 0.97 & 1.36 & 1.42 & 1.18 & 0.90 & 1.54 & 1.43 \\
\hline & Tcity & 1.10 & 0.97 & 0.88 & 1.04 & 1.12 & 0.69 & 1.06 & 1.14 \\
\hline & MIL 8 & 1.08 & 1.00 & 0.66 & 0.51 & 0.61 & 0.66 & 0.70 & 0.59 \\
\hline \multirow[t]{4}{*}{$\mathrm{Zn}$} & PAPA & 1.33 & 0.80 & 0.90 & 1.15 & 0.84 & 0.99 & 0.82 & 0.82 \\
\hline & S\&D & 1.07 & 0.98 & 1.10 & 1.03 & 0.98 & 0.93 & 1.13 & 1.02 \\
\hline & Tcity & 1.16 & 1.04 & 0.99 & 0.97 & 1.24 & 1.03 & 0.99 & 1.17 \\
\hline & MIL 8 & 1.03 & 0.96 & 0.93 & 0.65 & 0.82 & 0.79 & 0.63 & 0.61 \\
\hline \multirow[t]{4}{*}{$\mathrm{Fe}$} & PAPA & 1.27 & 0.98 & 0.93 & 0.98 & 0.91 & 0.97 & 0.96 & 0.86 \\
\hline & S\&D & 1.10 & 1.02 & 1.11 & 0.85 & 1.01 & 0.96 & 1.00 & 0.95 \\
\hline & Tcity & 1.38 & 1.35 & 1.17 & 1.10 & 1.35 & 1.24 & 1.10 & 1.38 \\
\hline & MIL 8 & 0.98 & 0.95 & 0.90 & 0.73 & 0.78 & 0.81 & 0.92 & 0.76 \\
\hline
\end{tabular}

Figures in bold indicate a degree of contamination or ecological risk. A $C_{f} \leqslant 1$ designates low pollution; $1<C_{f} \leqslant 3$ is moderate pollution; $3<C_{f} \leqslant 6$ is considerable pollution; and $C_{f}>6$ is very high pollution (Maanan etal., 2014)

\section{CONCLUSION}

This study investigated soil quality and metal loads in soils around four quarry sites within Abeokuta, Southwest Nigeria. Different indices were used to assess the degree of soil contamination with respect to these metals. Results of soil analysis showed soil quality (measured by $\mathrm{pH}$, OC, available $\mathrm{N}, \mathrm{P}$ and $\mathrm{K}$ ) reduced with increasing distances from the quarry gates. Metal concentrations also had strong and significant $(\mathrm{P}=0.05)$ negative relationships with distance. Almost all samples (Except two) had metal concentrations within permissible limits. Moderate contaminations for all metals were observed in soils collected close to the quarry gates soils. However, the results of ecological risk index $(E)$ showed that the metal loads in soils currently do not pose any ecological risk.

Soil quality and the presence of heavy metals in soils above permissible limits are harmful to the environment and can impact negatively on agricultural production. Inhabitants around the quarry sites in this study are mostly farmers whose crops may suffer reduced growth, whose water sources could become contaminated and who may come in contact with metal contaminants when they are released into the atmosphere via dust. Periodic monitoring of soil quality and metal contamination around these quarry sites is recommended.

\section{REFERENCES}

Adeyanju , E.and Okeke, C. 2019. Exposure effect to cement dust pollution: a mini review, SN Appl. Sci. (1): 1572 .

Akinse, A.G. and Gbadebo, A.M. 2016. Geological mapping of Abeokuta Metropolis, Southwestern Nigeria. Int J Sci Eng Res 7(8):979-983

Bilen,S. 2010. Effect of cement dust pollution on microbial properties and enzyme activities 
in cultivated and no-till soils, Afr. J. Microbiol. Res. 4 (22) : 2418-2425.

Das S. and Ting, Y. 2017. Evaluation of wet digestion methods for quantification of metal content in electronic scrap material. Resources 6(4), 64 ; https://doi.org/10.3390/resources6040 064

FAO. Food and Agricultural Organization. 2019. Standard operationg procedure for soil organic matter: Titration and Colorimetric method. Global Soil Laboratory Network.

Freitas,H., Prasad, M.N. and Pratas, J. 2004. Plant community tolerant to trace elements growing on the degraded soils of Sao Domingos mine in the south east of Portugal: environmental implications, Environ. Int. 30: 65-72.

He, X.T. Mulvaney, R.L. and Banwart, W.L. 1990. A rapid method for total nitrogen analysis using microwave digestion. Soil Science Society of America Journal, 54(6): 1625-1629. https://doi.org/10.2136/sssaj1990.0361 $5995005400060019 \mathrm{x}$

Julie, C., Renaud, J., Elise, B., Fabrice, B. and Thierry, D. 2018. Impact of quarry exploitation and disuse on pedogenesis. CATENA, Elsevier 160 (160): 354-365. 10.1016/j.catena.2017.09.012. hal01790691.

Koshiba, T., Kobayashi, M. and Matoh, T. 2009. Boron deficiency. Plant Signal Behav. 4: 557-8. doi:10.1093/pcp/pcn184. PMC 2688312. PMID 19816136.

Maanan,M., Saddik, M., Chaibi , M., Assobhei, O. and Zourarah, B. 2014. Environmental and ecological risk assessment of heavy metals in sediments of Nador lagoon, Morocco, Ecol. Indic. 48: 616-626.

Melodi, M.M. 2017. Assessment of Environmental Impacts of Quarry Operation in Ogun State, Nigeria .FUOYE Journal of Engineering and Technology, 2(2): 2579-0625

Morkunas, A. Wo 'zniak, V. Mai, R. Ruci 'nskaSobkowiak, Jeandet,P. 2018. The role of heavy metals in plant response to biotic stress, Molecules 23 (9) : 2320

Neina, D. 2019. The role of soil $\mathrm{pH}$ in plant nutrition and soil remediation. Applied and Environmental Soil Science. ID 5794869.

Nouri, M. and Haddioui, A. Assessment of metal contamination and ecological risk in AIT Ammar abandoned Iron mine soil, Morocco, Ekológia 35 (1) : 32-49

Oguntoke,O., Aboaba, A. and Gbadebo, T.A. 2009. Impact of granite quarrying on the health of workers and nearby residents in Abeokuta, Ogun State, Nigeria. Ethiopian Journal of Environmental Studies And Management 2,1-11.

Okebalama, C.B., Igwe, C.A. and Okolo, C.C. 2017. Soil organic carbon levels in soils of contrasting land uses in southeastern Nigeria. Tropical and Subtropical Agroecosystems 20 (3): 493-504

Olatunde K.A, Sosanya, P.; Bada, B., Ojekunle, Z, and Abdusalaam, S. 2020. Distribution and ecological risk assesement of heany metals in soils around a major cement factory, Ibese, Nigeria. Scientific African, Elsevier 9: e00495. Available at http://doi.org/10.1016/j.sciaf.2020.e004 96

Toth,G., Hermann, T. DaSilva, M.R. and Montanarella, L. 2016. Heavy metals in agricultural soils of the European Union with implications for food safety. Environment International 88: 299-309.

Zhang, J. and Liu, C.L. 2000. Riverine composition and estuarine geochemistry of particulate metals in China weathering features, anthropogenic impact and chemical fluxes, Estuar. Coast. Shelf Sci. 5:1051-1070.

Zwolak, A., Sarzyńska, M., Szpyrka, E. and Stawarczyk, K. 2019. Sources of Soil Pollution by Heavy Metals and Their Accumulation in Vegetables: a Review. Water, Air and Soil Pollution 230, Article 164. https://doi.org/10.1007/s11270019-4221-y. 